\title{
Disposisi Matematik Guru Matematika pada Pembelajaran dalam Jaringan di Masa Pandemi Covid-19
}

\author{
Riki Andriatna \\ Program Studi Pendidikan Matematika, FKIP Universitas Sebelas Maret \\ andriatna.riki@staff.uns.ac.id
}

\begin{abstract}
ABSTRAK
Pandemi Covid-19 telah menyebabkan pengaruh pada kegiatan pembelajaran, termasuk pada disposisi matematik guru matematika. Proses pembelajaran di sekolah dilakukan secara online semenjak pandemi. Penelitian ini bertujuan untuk mendeskripsikan disposisi matematik guru Matematika selama pembelajaran daring dimasa pandemi Covid-19. Metode penelitian menggunakan pendekatan kualitatif berbasis survei yang melibatkan 34 responden yang terdiri dari 19 guru Matematika SMA/SMK/MA dan 15 guru Matematika SMP/MTs. Instrumen penelitian menggunakan skala Likert yang terbagi menjadi enam indikator disposisi matematik yaitu: (1) kemandirian dalam proses bermatematika; (2) kemampuan menerapkan konsep matematika; (3) keinginan dan motivasi belajar matematika; (4) mengatasi diri sendiri dalam belajar matematika; (5) keinginan dan motivasi belajar dalam mengajar matematika secara daring; dan (6) mengatasi diri sendiri dalam mengajar matematika secara daring. Hasil penelitian menunjukkan bahwa kategori tinggi dicapai pada indikator (1), (2), (3), dan (5), sedangkan kategori sedang dicapai pada indikator (4) dan (6), sehingga keseluruhan disposisi matematik guru Matematika selama pembelajaran daring di masa Pandemi Covid-19 berada pada kategori tinggi dengan skor rata-rata 3,03. Penelitian ini menyarankan adanya tindak lanjut untuk mempertahankan dan meningkatkan disposisi matematik selama pembelajaran online.
\end{abstract}

Kata Kunci: Disposisi Matematik, Guru Matematika, Pembelajaran Daring.

\begin{abstract}
The Covid-19 pandemic has affected teaching and learning. Most of teaching and learning processes in schools are held in online form during the pandemic. The purpose of this study was to describe the mathematical dispositions of mathematics teachers during online teaching. Surveybased quantitative approach was used in this study by having 34 respondents, 19 teachers of senior high schools, and 15 teachers of junior high schools. The research instrument employed a Likert scale. Six indicators of mathematical disposition were used, namely: (1) independence in the process of doing mathematics; (2) ability to apply mathematical concepts; (3) willingness and motivation to learn mathematics; (4) ability to overcome own difficulties in learning mathematics; (5) willingness and motivation to learn how to teach mathematics through online teaching; and (6) ability to overcome own difficulties in online teaching. Levels of the teacher's mathematical disposition were classified into 3 categories: high, medium, and low. In each indicator, the result showed that high category was achieved in indicators (1), (2), (3), and (5), while the medium category was achieved in indicators (4) and (6). In total, the mean score of the teacher's mathematical disposition was 3.03 which in the high category. This study suggests that conducting follow-up actions in order to maintain and improve the teacher's mathematical disposition during online teaching is necessary.
\end{abstract}

Keywords: Mathematical Disposition, Mathematics Teacher, Online Learning. 


\section{A. PENDAHULUAN}

Seluruh negara sedang berjuang melawan pandemi dari Coronavirus Diseases (Covid-19) yang berdampak pada seluruh aspek kehidupan, tidak terkecuali aspek pendidikan (Herliandry dkk., 2020). Mengantisipasi meluasnya Covid-19, Pemerintah Indonesia melalui Kementerian Pendidikan dan Kebudayaan mengeluarkan Surat Edaran Menteri Pendidikan dan Kebudayaan Nomor 4 Tahun 2020 tentang Pelaksanaan Kebijakan Pendidikan dalam Masa Darurat Penyebaran Coronavirus Disease (Covid19) dan Surat Edaran Nomor 36961/MPK.A/HK/2020 perihal Pembelajaran Dalam Jaringan (Daring). Kedua surat tersebut menginstruksikan bahwa proses pembelajaran mengalami perubahan yang signifikan pada sisi teknis, dimana pada masa pandemi seluruh kegiatan pembelajaran dilakukan secara online atau dalam jaringan (daring). Hal ini tentu menjadi tantangan bagi seluruh guru bidang studi apapun yang terdampak pandemi, termasuk didalamnya adalah guru Matematika.

Pembelajaran matematika sejatinya dalam mencapai keberhasilannya dilakukan secara tatap muka (Khirwadkar dkk., 2020). Hal tersebut disebabkan karena sebagian konsep matematika yang bersifat abstrak (Adler dan Davis, 2006) sehingga mengharuskan siswa memahami secara mendalam berdasarkan pemahaman yang dibangun atas dasar pengalaman (Khirwadkar et al., 2020). Hal ini berimplikasi pada keharusan guru dalam menggunakan variasi model/strategi/metode pembelajaran. Dengan adanya Covid-19 ini, proses pembelajaran matematika dibatasi, terutama oleh ruang dimana Pemerintah Indonesia melalui Kementerian Pendidikan dan Kebudayaan mengalihkan kegiatan tatap muka secara langsung menjadi virtual (online). Menanggapi perubahan sisi teknis pembelajaran matematika, NCTM (2020) menjadikan teaching practice dan structure considerations sebagai salah aspek yang berimplikasi secara mendalam terhadap kesuksesan pembelajaran matematika di masa pandemi.

Terkait dengan efektivitas praktik mengajar, NCTM (2014) dalam Principles to Actions menyatakan terdapat beberapa hal yang menjadi perhatian, khususnya dari guru, diantaranya mengembangkan lingkungan sosial, emosional, dan akademis yang baik untuk pembelajaran matematika, yaitu lingkungan dimana siswa merasa aman dan percaya diri dalam kegiatan pembelajaran. Berkaitan dengan hal tersebut, yaitu dalam rangka membangun lingkungan yang menimbulkan rasa percaya diri pada siswa, sebaiknya harus dimulai dari rasa percaya diri dari seorang guru. Hal ini terkait dengan disposisi matematik pada seorang guru, terutama dimasa pandemi karena adanya perubahan aktivitas pembelajaran dari offline menjadi online dengan segala dinamikanya.

Disposisi merupakan kecenderungan atau kepercayaan seseorang untuk berperilaku (Biber dkk., 2013). Lebih lanjut menurut Kusmaryono dkk. (2019) bahwa tindakan yang dilakukan seseorang merupakan bentuk realisasi dari hasil 
pemikiran. Tindakan yang baik akan terjadi jika fungsi mental dalam kondisi baik, sehingga secara psikologi, disposisi berhubungan erat dengan fungsi mental (Kusmaryono et al., 2019). Ini berarti semakin tinggi tingkat disposisi, maka semakin terarah tindakan seseorang.

Disposisi matematis merupakan kecenderungan seseorang untuk memandang matematika sebagai sesuatu yang mudah dipahami dan berguna, percaya pada usaha yang tekun dalam belajar matematika akan berbuah pemahaman yang baik, dan melakukan tindakan belajar yang efektif (Kilpatrick et al., 2001). Sejalan dengan itu, NCTM (1989) telah menegaskan bahwa disposisi matematik tidak hanya sekedar keyakinan atau sikap, tetapi berupa kecenderungan berpikir dan bertindak dengan cara yang positif, sehingga disposisi matematik memuat tujuh komponen, yaitu: (1) percaya diri dalam menggunakan matematika; (2) fleksibel dalam bermatematika; (3) gigih dalam menyelesaikan masalah matematika; (4) memiliki rasa ingin tahu dalam matematika; (5) refleksi terhadap cara berpikirnya; (6) mengapresiasi terhadap penerapan (aplikasi) matematika; dan (7) mengapresiasi peranan matematika. Berdasarkan kedua hal di atas, diposisi matematis guru matematika merupakan kecenderungan berpikir dan bertindak positif terhadap matematika, termasuk didalamnya mempelajari dan menyelesaikan permasalahan matematika serta mengajarkan matematika kepada siswa.
Mengajarkan matematika bagi seorang guru dimasa pandemi memiliki tantangan sekaligus usaha yang berbeda dibandingkan dengan mengajarkan matematika pada kondisi sebelum pandemi. Adanya penggunaan media interaksi dan komunikasi berupa pemanfaatan teknologi dalam pembelajaran memberikan dampak terhadap kepercayaan seorang guru dalam melakukan proses pembelajaran (Marpa, 2021). Selain itu, adanya pemanfaatan teknologi dalam proses pembelajaran daring selama pandemi juga berdampak kurang baik pada hasil belajar siswa dibandingkan dengan pembelajaran offline sebelum pandemi (Ariyanti \& Santoso, 2020). Pada sisi lain, kecemasan dan rasa kurang percaya diri siswa pada saat pandemi menjadi tinggi (Simorangkir et al., 2021), untuk itu seorang guru diharuskan menjaga rasa percaya diri siswa yang ditumbuhkan dari rasa percaya diri guru matematika (Furner \& Higgins, 2019). Ulia dan Kusmaryono (2021) menyatakan bahwa motivasi termasuk didalamnya disposisi matematik siswa dan guru tetap harus dijaga. Kondisi tersebut diperlukan, terutama dalam menjalankan pembelajaran daring di masa pandemi.

Disposisi matematik pada sisi siswa pada saat pembelajaran daring sudah diteliti (Fadillah et al., 2020; Melinda \& Lazwardi, 2020) dan sebelum pembelajaran daring (Adi dkk., 2019; Clark dkk., 2014; Kusmaryono dkk., 2019). Sedangkan pada sisi guru, penelitian mengenai disposisi dilakukan selama pembelajaran daring diantaranya Ulia dan Kusmaryono (2021) yang 
mana penelitian tersebut berfokus pada guru Sekolah Dasar. Dijelaskan lebih lanjut bahwa keberhasilan pembelajaran daring selama pandemi dipengaruhi oleh disposisi dari guru (Ulia \& Kusmaryono, 2021). Oleh karena itu diperlukan suatu studi untuk mengetahui disposisi matematik guru Matematika selama pembelajaran daring, yaitu kemampuan disposisi matematik guru matematika untuk sekolah menengah, baik SMP/MTs dan SMA/SMK/MA.

\section{B. METODE}

Penelitian ini merupakan penelitian kuantitatif dengan metode survei yang bertujuan untuk mengetahui disposisi matematis guru Matematika SMP/MTs dan SMA/SMK/MA selama pembelajaran daring. Penelitian melibatkan 34 responden yang terdiri dari 19 guru Matematika SMA/SMK/MA dan 15 guru Matematika SMP/MTs yang melaksanakan pembelajaran daring pada kurun waktu Maret 2020 sampai dengan Maret 2021. Ukuran tersebut menurut Roscoe (Sugiyono, 2015) sudah layak dalam penelitian.

Instrumen pada penelitian ini menggunakan instrumen non tes berupa skala sikap model Likert (Sangat Setuju (SS), Setuju (S), Tidak Setuju (TS), dan Sangat Tidak Setuju(STS)) yang terdiri dari 36 pernyataan, dengan 20 pernyataan positif dan 16 pernyataan negatif, yang terbagi ke dalam enam indikator yang dimodifikasi dari Juandi dkk. (2015). Adapun keenam indikator disposisi matematik yaitu: (1) kemandirian dalam proses bermatematika, yaitu merujuk pada kemampuan dan usaha guru dalam mempelajari matematika dan menyelesaikan permasalahannya secara mandiri; kemampuan menerapkan konsep matematika, yaitu kemampuan dalam menyelesaikan permasalahan matematika, termasuk menyajikan gagasan tertulis matematika/hasil penelitian; (3) keinginan dan motivasi belajar matematika, yaitu antusias dan motivasi guru dalam mempelajari matematika; (4) mengatasi diri sendiri dalam belajar matematika, yaitu kemampuan dan usaha yang dilakukan guru dalam mengatasi kesulitan dalam mempelajari matematika; (5) keinginan dan motivasi belajar dalam mengajar matematika secara daring, yaitu sikap dan kemampuan guru dalam mengajarkan matematika selama pandemi; dan (6) mengatasi diri sendiri dalam mengajar matematika secara daring, yaitu sikap dan usaha guru dalam mengatasi permasalahan selama pembelajaran daring. Instrumen diberikan kepada responden melalui daring menggunakan Google form dengan cara mengirimkan melalui aplikasi pesan.

Reliabilitas instrumen penelitian dihitung menggunakan Cronbach's Alpha dengan nilai 0,909, sehingga memenuhi kriteria reliabilitas tinggi (Taber, 2018). Adapun validitas instrumen berupa validitas isi dilakukan dengan meminta pendapat ahli berkaitan dengan butir-butir pernyataan.

Tahapan penelitian survei dilakukan dengan mengikuti tahapan yang diadaptasi dari Ulia dan Kusmaryono (2021) sebagai berikut: 
(1) menentukan masalah penelitian melalui analisis situasi; (2) mengembangkan instrumen non tes berupa skala sikap model Likert; (3) penentuan responden dan menyebarkan instrumen; (4) pengumpulan data dan analisis data; dan (5) penarikan kesimpulan. Analisis data hasil survei menggunakan teknik persentase, yaitu melihat frekuensi jawaban dari responden dan ukuran statistik deskriptif ratarata. Pernyataan pada skala Likert terdiri dari pernyataan positif dan negatif dengan acuan pemberian skor diadaptasi dari Sugiyono (2015) sebagai berikut.

Tabel 1. Skor Skala Likert

\begin{tabular}{lcccc}
\hline Pernyataan & SS & S & TS & STS \\
\hline Positif & 4 & 3 & 2 & 1 \\
\hline Negatif & 1 & 2 & 3 & 4 \\
\hline
\end{tabular}

Adapun kategori disposisi matematik (DM) sebagai berikut (Ulia \& Kusmaryono, 2021).

Tabel 2. Kategori Disposisi Matematik (DM)

\begin{tabular}{cc}
\hline Kategori & Interval \\
\hline Tinggi & $3<\mathrm{DM} \leq 4$ \\
\hline Sedang & $2<\mathrm{DM} \leq 3$ \\
\hline Rendah & $1<\mathrm{DM} \leq 2$ \\
\hline
\end{tabular}

Hasil pengkategorian disposisi matematik tersebut selanjutnya divalidasi dengan memperhatikan pandangan responden dengan berbagai pendapat ahli.

\section{HASIL DAN PEMBAHASAN}

Data penelitian diperoleh dari 34 responden yang terdiri dari 19 guru Matematika tingkat SMA/SMK dan 15 guru Matematika tingkat SMP/MTs. Para responden berasal dari provinsi di Pulau Jawa dan Pulau Sumatera yaitu Provinsi Jawa Barat 24 responden, Provinsi Jawa Tengah 4 responden, Provinsi Jawa Timur 2 responden, Provinsi DKI Jakarta 1 responden, dan 3 responden berasal dari Pulau Sumatera. Berikut disajikan hasil persentase dan rata-rata skor jawaban setiap indikator disposisi matematik.

\section{Kemandirian dalam Proses Bermatematika}

Indikator kemandirian dalam proses bermatematika terdiri dari lima pernyataan. Adapun hasil survei indikator kemandirian dalam proses bermatematika disajikan pada Tabel 3 di bawah. Berdasarkan Tabel 3 diperoleh bahwa kategori disposisi matematik pada indikator kemandirian dalam proses bermatematika adalah tinggi dengan skor rata-rata 3,09. Selain itu, tiga dari lima pernyataan memiliki kategori tinggi dengan skor rata-rata tertinggi adalah 3,35 pada pernyataan keempat.

Sebagaimana diketahui bahwa antar materi dalam matematika memiliki keterkaitan satu dengan yang lainnya sehingga satu konsep dapat menjadi konsep prasyarat untuk mempelajari konsep/materi selanjutnya. Sebaliknya skor rata-rata terendah adalah 2,79 pada pernyataan ketiga. Kondisi tersebut sejalan dengan Sumardyono (2018) bahwa kemampuan guru dalam menyusun bukti dalam pembelajaran matematika masih kurang. Lebih lanjut dijelaskan oleh Sumardyono (2018) bahwa kondisi tersebut dapat dimungkinkan karena pembuktian matematis pada jenjang sekolah menengah tidak muncul secara eksplisit. Namun demikian, kemampuan dalam pembuktian 
matematis, khususnya bagi guru matematika, merupakan sesuatu hal yang sangat penting dalam proses pembelajaran sehingga pemahaman terhadap matematika menjadi kuat. Hal ini tentu akan berdampak positif terhadap disposisi matematik guru matematika.

Tabel 3. Hasil Survei Indikator Kemandirian dalam Proses Bermatematika

\begin{tabular}{|c|c|c|c|c|c|c|}
\hline \multirow{2}{*}{ Pernyataan } & \multicolumn{4}{|c|}{ Sikap (\%) } & \multirow{2}{*}{$\begin{array}{l}\text { Rata- } \\
\text { rata } \\
\text { Skor }\end{array}$} & \multirow{2}{*}{ Kategori } \\
\hline & SS & $S$ & TS & STS & & \\
\hline $\begin{array}{l}\text { Saya mampu memahami materi matematika } \\
\text { sekolah tanpa bantuan orang lain atau teman } \\
\text { sejawat }\end{array}$ & 38,2 & 38,2 & 23,6 & 0,0 & 3,15 & Tinggi \\
\hline $\begin{array}{l}\text { Saya tidak memahami konsep-konsep matematika } \\
\text { sekolah pada tingkatan yang tinggi }\end{array}$ & 0,0 & 23,5 & 55,9 & 20,6 & 2,97 & Sedang \\
\hline $\begin{array}{l}\text { Saya tidak berusaha membuktikan/ menunjukkan } \\
\text { sendiri kebenaran dari sifat-sifat atau teorema } \\
\text { dalam matematika sekolah }\end{array}$ & 0,0 & 38,2 & 44,1 & 17,7 & 2,79 & Sedang \\
\hline $\begin{array}{l}\text { Saya mempelajari keterkaitan antar konsep dalam } \\
\text { matematika sekolah }\end{array}$ & 38,2 & 58,8 & 3,0 & 0,0 & 3,35 & Tinggi \\
\hline $\begin{array}{l}\text { Saya berusaha menemukan cara tersendiri dalam } \\
\text { menyelesaikan permasalahan matematika sekolah } \\
\text { (soal) }\end{array}$ & 29,4 & 58,8 & 11,8 & 0,0 & 3,18 & Tinggi \\
\hline
\end{tabular}

\section{Kemampuan} Matematika

Indikator kemampuan menerapkan konsep matematika terdiri dari enam pernyataan. Pada Tabel 4 disajikan hasil survei indikator kemampuan menerapkan konsep matematika. Tabel 4 menyajikan hasil jawaban responden terhadap pernyataan-pernyataan pada indikator kemampuan menerapkan konsep matematika, yaitu menunjukkan empat dari enam pernyataan berada pada kategori tinggi dengan skor ratarata tertinggi adalah 3,41 .

Secara keseluruhan, skor rata-rata indikator adalah 3,02 (tinggi). Indikator ini menyiratkan gabungan beberapa kemampuan matematika, yaitu salah satunya kemampuan pemecahan masalah.

Disposisi matematik dan kemampuan pemecahan masalah memiliki keterkaitan yang penting. Kurniawan dan Kadarisma (2020) menyatakan bahwa disposisi sebagai suatu soft skill berperan penting dalam bertahan untuk mencari solusi dari suatu permasalahan. Hal ini menguatkan hasil yang diperoleh bahwa disposisi matematik guru pada kemampuan menerapkan konsep matematika, khususnya pada aspek memecahkan masalah berada pada kategori tinggi, hal ini menunjukkan bahwa disposisi memiliki peran penting dalam menyelesaikan masalah matematika. 
Tabel 4. Hasil Survei Indikator Kemampuan Menerapkan Konsep Matematika

\begin{tabular}{|c|c|c|c|c|c|c|}
\hline \multirow{2}{*}{ Pernyataan } & \multicolumn{4}{|c|}{ Sikap (\%) } & \multirow{2}{*}{$\begin{array}{l}\text { Rata- } \\
\text { rata } \\
\text { Skor }\end{array}$} & \multirow{2}{*}{ Kategor } \\
\hline & SS & $S$ & TS & STS & & \\
\hline $\begin{array}{l}\text { Saya dapat memecahkan masalah-masalah } \\
\text { matematika sekolah berdasarkan konsep-konsep } \\
\text { matematika yang telah dipahami }\end{array}$ & 41,2 & 58,8 & 0,0 & 0,0 & 3,41 & Tinggi \\
\hline $\begin{array}{l}\text { Saya masih bingung dalam mengaitkan beberapa } \\
\text { konsep matematika sekolah, terutama dalam } \\
\text { konteks penerapan konsep }\end{array}$ & 2,9 & 26,5 & 52,9 & 17,7 & 2,85 & Sedang \\
\hline $\begin{array}{l}\text { Saya tertarik dalam membuat karya, seperti karya } \\
\text { tulis, alat peraga, atau lainnya, mengenai konsep } \\
\text { matematika sekolah }\end{array}$ & 20,6 & 58,8 & 20,6 & 0,0 & 3,00 & Sedang \\
\hline $\begin{array}{l}\text { Saya mengalami kesulitan dalam menerapkan } \\
\text { berbagai rumus matematika sekolah }\end{array}$ & 0,0 & 14,7 & 61,8 & 23,5 & 3,09 & Tinggi \\
\hline $\begin{array}{l}\text { Saya tertantang untuk mencari penerapan dari } \\
\text { materi matematika sekolah yang saya kuasai }\end{array}$ & 20,6 & 70,6 & 5,9 & 2,9 & 3,09 & Tinggi \\
\hline $\begin{array}{l}\text { Masih terdapat beberapa materi matematika } \\
\text { sekolah yang belum saya pahami dengan baik }\end{array}$ & 0,0 & 50,0 & 32,4 & 17,6 & 2,68 & Sedang \\
\hline
\end{tabular}

\section{Keinginan dan Motivasi Belajar Matematika}

Tabel 5 merupakan hasil survei terhadap indikator keinginan dan motivasi belajar matematika untuk diposisi matematik yang menunjukkan bahwa enam dari tujuh pernyataan menunjukkan kategori tinggi pada indikator keinginan dan motivasi belajar matematika meskipun pada kondisi pandemi.

Adapun skor rata-rata keseluruhan adalah 3,23. Hal ini menunjukkan bahwa keinginan dan motivasi guru dalam belajar matematika dimasa pandemi tinggi. Keinginan dan motivasi guru dalam belajar matematika termasuk dalam proses pembelajaran menjadi salah satu faktor yang dapat menunjang keberhasilan pembelajaran termasuk prestasi belajar siswa. Michaelowa (Sahat dkk., 2018) menyatakan bahwa kualitas pengajaran akan terkait dengan motivasi guru. Annajmi (2018) yang menyatakan bahwa salah satu faktor yang berpengaruh terhadap prestasi belajar siswa adalah guru. Dengan keinginan dan motivasi guru yang tinggi (disposisi matematik) dimasa pandemi diharapkan berdampak pada prestasi belajar siswa.

Tabel 5. Hasil Survei Indikator Keinginan dan Motivasi Belajar Matematika

\begin{tabular}{llllllll}
\hline \multirow{1}{*}{ Pernyataan } & \multicolumn{4}{c}{ Sikap (\%) } & & $\begin{array}{c}\text { Rata- } \\
\text { rata }\end{array}$ & Kategori \\
\cline { 2 - 6 } & SS & S & TS & STS & Skor & \\
\hline $\begin{array}{l}\text { Saya antusias dalam mengikuti diskusi mengenai } \\
\text { konsep matematika atau pemecahan masalah } \\
\text { matematika }\end{array}$ & 50,0 & 50,0 & 0,0 & 0,0 & 3,50 & Tinggi \\
\hline
\end{tabular}




\begin{tabular}{|c|c|c|c|c|c|c|}
\hline \multirow{2}{*}{ Pernyataan } & \multicolumn{4}{|c|}{ Sikap (\%) } & \multirow{2}{*}{$\begin{array}{l}\text { Rata- } \\
\text { rata } \\
\text { Skor }\end{array}$} & \multirow{2}{*}{ Kategori } \\
\hline & SS & $S$ & TS & STS & & \\
\hline $\begin{array}{l}\text { Terhadap permasalahan matematika yang belum } \\
\text { terselesaikan, saya tidak penasaran untuk dapat } \\
\text { segera memecahkannya }\end{array}$ & 2,9 & 5,9 & 61,8 & 29,4 & 3,18 & Tinggi \\
\hline $\begin{array}{l}\text { Soal-soal matematika berupa pembuktian saya } \\
\text { hindari }\end{array}$ & 2,9 & 14,7 & 67,7 & 14,7 & 3,62 & Tinggi \\
\hline $\begin{array}{l}\text { Saya berminat untuk mempelajari materi } \\
\text { matematika pada jenjang yang lebih tinggi }\end{array}$ & 35,3 & 55,9 & 8,8 & 0,0 & 3,26 & Tinggi \\
\hline $\begin{array}{l}\text { Ketika orang lain sedang membahas pemecahan } \\
\text { masalah matematika, saya tertarik untuk } \\
\text { mengikutinya }\end{array}$ & 35,3 & 64,7 & 0,0 & 0,0 & 3,35 & Tinggi \\
\hline $\begin{array}{l}\text { Terhadap semua materi matematika yang belum } \\
\text { saya pahami, saya tidak berusaha untuk } \\
\text { mempelajarinya secara mendalam }\end{array}$ & 0,0 & 11,8 & 67,6 & 20,6 & 3,09 & Tinggi \\
\hline $\begin{array}{l}\text { Saya merasa cukup dalam memahami materi } \\
\text { matematika sekolah }\end{array}$ & 5,9 & 55,9 & 32,3 & 5,9 & 2,62 & Sedang \\
\hline
\end{tabular}

\section{Mengatasi Diri Sendiri dalam Belajar Matematika}

Indikator keempat dari disposisi matematik adalah kemampuan mengatasi diri sendiri dalam belajar matematika, yaitu melihat bagaimana guru dalam mengatasi hambatan yang dialami ketika mempelajari materi matematika, terutama materi yang akan diajarkan kepada siswa. Berdasarkan hasil pada Tabel 6 diperoleh skor rata-rata secara keseluruhan adalah 2,93. Hal ini menunjukkan bahwa kemampuan mengatasi hambatan yang dialami termasuk pada kategori sedang. Dari tiga pernyataan pada tabel 6 diperoleh sikap bahwa sebagian besar guru tidak setuju jika menghafal semua rumusrumus matematika dan tidak meminta bantuan kepada orang lain ketika mengalami hambatan dalam memahami materi matematika.

Gafoor dan Kurukkan (2015) menyatakan bahwa matematika adalah sesuatu yang unik, abstrak, dan tuntutan proses kognitif yang tinggi menyebabkan tantangan sekaligus kesulitan tersendiri. Dengan adanya kesulitan tersebut, memberikan suatu tantangan bagaimana guru dalam menyikapinya. Sejalan dengan hasil survei yang dilakukan, Gafoor dan Kurukkan (2015) menyatakan bahwa pencarian bantuan, salah satunya referensi, merupakan sesuatu kemungkinan yang dapat dilakukan. Hal ini sekaligus merupakan suatu kemandirian guru dalam melakukan proses belajar matematika.

Tabel 6. Hasil Survei Indikator Mengatasi Diri Sendiri dalam Belajar Matematika

\begin{tabular}{lcccccccc}
\hline \multirow{2}{*}{ Pernyataan } & \multicolumn{4}{c}{ Sikap (\%) } & & \multicolumn{2}{c}{ Rata- } \\
\cline { 2 - 5 } & SS & S & TS & STS & $\begin{array}{l}\text { Sata } \\
\text { Skor }\end{array}$ & Kategori \\
\hline $\begin{array}{l}\text { Saya berusaha menghafal semua rumus } \\
\text { matematika }\end{array}$ & 2,9 & 38,3 & 55,9 & 2,9 & 2,59 & Sedang \\
\hline
\end{tabular}




\begin{tabular}{llllllll}
\hline \multicolumn{1}{c}{ Pernyataan } & \multicolumn{4}{c}{ Sikap (\%) } & & $\begin{array}{c}\text { Rata- } \\
\text { rata } \\
\text { Skor }\end{array}$ & Kategori \\
\cline { 2 - 6 } & SS & S & TS & STS & \\
\hline $\begin{array}{l}\text { Ketika menemui kesulitan dalam memahami } \\
\text { materi matematika sekolah, saya tidak meminta } \\
\text { bantuan orang lain untuk membantu saya dalam } \\
\text { memahami materi tersebut }\end{array}$ & 5,9 & 17,6 & 64,7 & 11,8 & 2,82 & Sedang \\
\hline $\begin{array}{l}\text { Saya mencari referensi/sumber relevan untuk } \\
\text { membantu mengatasi kekurangan dalam } \\
\text { memahami materi matematika sekolah }\end{array}$ & 47,1 & 44,1 & 8,8 & 0,0 & 3,38 & Tinggi \\
\hline
\end{tabular}

\section{Keinginan dan Motivasi Belajar dalam Mengajar Matematika secara Daring}

Tabel 7 merupakan hasil survei pada indikator keinginan dan motivasi belajar dalam mengajar matematika secara daring. Indikator ini menunjukkan antusiasme guru dalam meningkatkan kompetensi pedagogi khususnya untuk mengajarkan matematika. Berdasarkan Tabel 7 diperoleh skor rata-rata keseluruhan untuk indikator ini adalah 3,15. Hal ini menunjukkan bahwa para guru dimasa pembelajaran daring berada pada kategori kuat pada keinginan dan motivasi belajar dalam mengajar matematika secara daring.

Hal tersebut menunjukkan bahwa dari sebagian besar guru memiliki keinginan yang tinggi untuk meningkatkan kemampuan diri dalam melaksanakan pembelajaran matematika.
Akibatnya, dorongan dan rasa kepercayaan diri dalam berpikir dan bertindak positif terhadap matematika, khususnya dalam melakukan proses pembelajaran, masih tinggi.

Situasi pandemi Covid-19 yang melanda seluruh negara berdampak pada perubahan metode/strategi kegiatan pembelajaran, yaitu perubahan dari kegiatan tatap muka langsung menjadi pembelajaran daring. Perubahan signifikan tersebut tentunya mempengaruhi aspek psikis, baik guru maupun siswa. Beberapa penelitian menunjukkan bahwa motivasi belajar siswa saat daring tergolong rendah (Nurfallah \& Pradipta, 2021; Wijayanti \& Widodo, 2021). Menghadapi kondisi tersebut, disposisi matematik dari guru matematika merupakan suatu hal krusial sehingga diharapkan hasil motivasi dan hasil belajar siswa menjadi baik.

Tabel 7. Hasil Survei Indikator Keinginan dan Motivasi Belajar dalam Mengajar Matematika secara Daring

\begin{tabular}{|c|c|c|c|c|c|c|}
\hline \multirow{2}{*}{ Pernyataan } & \multicolumn{4}{|c|}{ Sikap (\%) } & \multirow{2}{*}{$\begin{array}{l}\text { Rata- } \\
\text { rata } \\
\text { Skor }\end{array}$} & \multirow{2}{*}{ Kategor } \\
\hline & SS & $\mathbf{S}$ & TS & STS & & \\
\hline $\begin{array}{l}\text { Saya antusias ketika ditanya mengenai materi } \\
\text { matematika sekolah }\end{array}$ & 32,4 & 64,7 & 2,9 & 0,0 & 3,29 & Tinggi \\
\hline $\begin{array}{l}\text { Terhadap berbagai model/metode/strategi } \\
\text { pembelajaran, khususnya untuk pembelajaran di } \\
\text { masa pandemi pada mata pelajaran matematika, } \\
\text { saya tertarik untuk mempelajarinya }\end{array}$ & 17,6 & 76,5 & 5,9 & 0,0 & 3,12 & Tinggi \\
\hline $\begin{array}{l}\text { Saya tidak yakin akan berhasil dalam mengajar } \\
\text { matematika di sekolah di masa pandemi }\end{array}$ & 2,9 & 20,6 & 67,7 & 8,8 & 2,82 & Sedang \\
\hline
\end{tabular}




\begin{tabular}{|c|c|c|c|c|c|c|}
\hline \multirow{2}{*}{ Pernyataan } & \multicolumn{4}{|c|}{ Sikap (\%) } & \multirow{2}{*}{$\begin{array}{l}\text { Rata- } \\
\text { rata } \\
\text { Skor }\end{array}$} & \multirow{2}{*}{ Kategori } \\
\hline & SS & $S$ & TS & STS & & \\
\hline $\begin{array}{l}\text { Saya tidak percaya diri dalam menghadapi tantangan } \\
\text { pembelajaran matematika di masa pandemi }\end{array}$ & 0,0 & 8,8 & 73,5 & 17,7 & 3,09 & Tinggi \\
\hline $\begin{array}{l}\text { Saya antusias mempelajari berbagai aplikasi/learning } \\
\text { manajemen sistem untuk pembelajaran matematika } \\
\text { dalam jaringan (daring) }\end{array}$ & 47,1 & 47,1 & 5,8 & 0,0 & 3,41 & Tinggi \\
\hline
\end{tabular}

6. Mengatasi Diri Sendiri dalam Mengajarkan Matematika secara Daring

Indikator disposisi matematis keenam adalah kemampuan mengatasi dalam mengajar matematika yang dilakukan secara daring. Adapun hasil survei disajikan pada Tabel 8 di bawah.

Tabel 8 memperlihatkan bahwa tujuh dari sepuluh pernyataan pada indikator ini menunjukkan kategori sedang, sehingga skor rata-rata keseluruhan pada indikator ini adalah 2,78 yang termasuk kategori sedang. Skor rata-

Tabel 8. Hasil Survei Indikator Mengatasi Diri Sendiri dalam Mengajarkan Matematik secara Daring

\begin{tabular}{|c|c|c|c|c|c|c|}
\hline \multirow{2}{*}{ Pernyataan } & \multicolumn{4}{|c|}{ Sikap (\%) } & \multirow{2}{*}{$\begin{array}{l}\text { Rata- } \\
\text { rata } \\
\text { Skor }\end{array}$} & \multirow{2}{*}{ Kategori } \\
\hline & SS & $S$ & TS & STS & & \\
\hline $\begin{array}{l}\text { Saya menguasai prosedur penggunaan } \\
\text { aplikasi/learning manajemen sistem yang digunakan } \\
\text { selama pembelajaran dalam jaringan (daring) }\end{array}$ & 35,3 & 52,9 & 11,8 & 0,0 & 3,24 & Tinggi \\
\hline $\begin{array}{l}\text { Menurut saya, matematika sulit untuk diajarkan } \\
\text { secara tidak langsung }\end{array}$ & 11,8 & 38,2 & 44,1 & 5,9 & 2,44 & Sedang \\
\hline $\begin{array}{l}\text { Saya mampu menerapkan teori pembelajaran dalam } \\
\text { matematika, khususnya selama pembelajaran dalam } \\
\text { jaringan (daring) }\end{array}$ & 8,8 & 52,9 & 38,2 & 0,0 & 2,71 & Sedang \\
\hline $\begin{array}{l}\text { Saya kesulitan dalam menyusun rencana } \\
\text { pembelajaran untuk pembelajaran dalam jaringan } \\
\text { (daring) }\end{array}$ & 5,9 & 29,4 & 58,8 & 5,9 & 2,65 & Sedang \\
\hline $\begin{array}{l}\text { Saya khawatir cara mengajarkan matematika dalam } \\
\text { jaringan (daring) tidak sesuai dengan kebutuhan dan } \\
\text { kondisi siswa }\end{array}$ & 8,8 & 76,5 & 11,8 & 2,9 & 2,09 & Sedang \\
\hline $\begin{array}{l}\text { Saya menguasai teknik evaluasi proses pembelajaran } \\
\text { selama pembelajaran dalam jaringan (daring) }\end{array}$ & 5,9 & 55,9 & 38,2 & 0,0 & 2,68 & Sedang \\
\hline $\begin{array}{l}\text { Saya mempelajari orang lain mengajarkan } \\
\text { matematika dalam jaringan (daring) melalui Youtube } \\
\text { atau media online lainnya }\end{array}$ & 20,6 & 58,8 & 20,6 & 0,0 & 3,00 & Sedang \\
\hline
\end{tabular}




\begin{tabular}{lccccccc}
\hline \multicolumn{1}{c}{ Pernyataan } & \multicolumn{3}{c}{ Sikap (\%) } & & \multicolumn{2}{c}{$\begin{array}{c}\text { Rata- } \\
\text { rata } \\
\text { Skor }\end{array}$} & Kategori \\
\cline { 2 - 6 } & SS & S & TS & STS & Skorn \\
\hline $\begin{array}{l}\text { Saya berusaha untuk mencari kelemahan diri dalam } \\
\text { pembelajaran dalam jaringan (daring) }\end{array}$ & 17,6 & 76,5 & 2,9 & 2,9 & 3,06 & Tinggi \\
\hline $\begin{array}{l}\text { Saya tidak meminta orang lain/teman sejawat untuk } \\
\text { mengevaluasi proses pembelajaran yang dilakukan } \\
\text { secara daring }\end{array}$ & 0,0 & 29,4 & 64,7 & 5,9 & 2,76 & Sedang \\
\hline $\begin{array}{l}\text { Selama pembelajaran dalam jaringan di masa } \\
\text { pandemi ini, saya hanya menggunakan satu aplikasi } \\
\text { pembelajaran }\end{array}$ & 0,0 & 5,9 & 76,5 & 17,6 & 3,12 & Tinggi \\
\hline
\end{tabular}

Selanjutnya disajikan rekapitulasi skor rata-rata keseluruhan untuk setiap indikator disposisi matematis sebagai berikut.

Tabel 9. Rekapitulasi Skor Rata-Rata Indikator Disposisi Matematik

\begin{tabular}{lcc}
\multicolumn{1}{c}{ Indikator } & $\begin{array}{c}\text { Skor Rata- } \\
\text { Rata }\end{array}$ & Kategori \\
\hline Kemandirian dalam proses bermatematika & 3,09 & Tinggi \\
\hline Kemampuan menerapkan konsep matematika & 3,02 & Tinggi \\
\hline Keinginan dan motivasi belajar matematika & 3,23 & Tinggi \\
\hline Mengatasi diri sendiri dalam belajar matematika & 2,93 & Sedang \\
\hline Keinginan dan motivasi belajar dalam mengajar matematika secara daring & 3,15 & Tinggi \\
\hline Mengatasi diri sendiri dalam mengajar matematika (secara daring) & 2,78 & Sedang \\
\hline
\end{tabular}

Berdasarkan Tabel 9 diperoleh bahwa dua dari enam indikator disposisi matematik berada pada kategori tinggi, sedang sisanya kategori sedang. Rata-rata keseluruhan diposisi matematik guru Matematika SMP/MTs dan SMA/SMK/MA selama pembelajaran daring dimasa pandemi COVID-19 adalah 3,03 dengan kategori tinggi. Meskipun berada pada kategori tinggi, sebagian besar interval skor rata-rata untuk kategori tinggi masih kurang dari 3,5. Dengan hasil tersebut, diharapkan bahwa dengan kemampuan disposisi matematik yang tinggi, berupa sikap dan kepercayaan yang positif dari guru diharapkan dapat memberikan dampak positif terhadap pembelajaran matematika sehingga berkorelasi positif dengan prestasi siswa. Hal tersebut sebagaimana diungkapkan Mazana dkk. (2019) bahwa sikap positif guru terhadap matematika dapat berkorelasi positif dengan prestasi siswa.

Indikator keinginan dan motivasi belajar matematika dan juga mengajar matematika dari guru Matematika berdasarkan hasil survei memperoleh skor rata-rata tertinggi dibandingkan dengan indikator lainnya. Hal ini menunjukkan bahwa guru Matematika masih antusias untuk mempelajari matematika dan mengajarkan matematika meskipun pada kondisi pandemi. Merujuk pada indikator disposisi matematik dari NCTM (1989) indikator 
tersebut termasuk pada aspek curiosity in mathematics. Kondisi tersebut tentu diharapkan akan berdampak positif pada disposisi siswa. OECD (2020) menyatakan bahwa antusiasme guru merupakan salah satu yang dapat mempengaruhi sikap dan disposisi siswa terhadap pembelajaran sehingga dapat memaksimalkan pembelajaran daring.

\section{PENUTUP}

\section{Kesimpulan}

Kondisi pandemi Covid-19 telah memberikan dampak pada pembelajaran Matematika, salah satunya pada disposisi matematik dari guru Matematika. Berdasarkan hasil penelitian diperoleh bahwa disposisi matematik guru Matematika berada pada kategori tinggi dengan pada indikator kemandirian dalam proses bermatematika, kategori tinggi pada indikator kemampuan menerapkan konsep matematika, kategori tinggi pada indikator keinginan dan motivasi belajar matematika, kategori sedang pada indikator mengatasi diri sendiri dalam belajar matematika, kategori tinggi pada keinginan dan motivasi belajar dalam mengajar matematika secara daring, dan kategori sedang pada indikator mengatasi diri sendiri dalam mengajar matematika secara daring. Secara keseluruhan, diposisi matematik guru Matematika berada pada kategori tinggi.

\section{Saran}

Berdasarkan hasil yang diperoleh, hendaknya guru Matematika untuk dapat terus meningkatkan sikap dan rasa kepercayaan diri terhadap matematika termasuk untuk berpikir positif terhadap matematika sehingga diharapkan dapat berdampak positif terhadap prestasi belajar siswa dalam bidang matematika. Salah satu aspek yang perlu diperhatikan adalah berkaitan dengan kemandirian dan kemauan untuk melakukan belajar mandiri mengenai materi matematika sehingga salah satu indikator disposisi, yaitu mengatasi diri sendiri dalam belajar matematika diharapkan dapat meningkat.

Disamping itu, penelitian melibatkan guru yang sebagian besar berasal dari Pulau Jawa yang merupakan keterbatasan dalam penelitian ini. Untuk itu, penelitian selanjutnya diharapkan dapat melibatkan responden guru dalam lingkup yang lebih luas.

\section{DAFTAR PUSTAKA}

Adi, M., Siregar, P., \& Lisma, E. (2019). The Effect of Disposition Student Mathematics Learning Achievement in Medan State 28 Junior High School. Journal of Community Service and Research, 3(1), 22-27. https://doi.org/doi.org/10.24114/jcrs.v3i1 .14402 .

Adler, J., \& Davis, Z. (2006). Opening another black box: Researching mathematics for teaching in mathematics teacher education. Journal for Research in Mathematics Education, 37(4), 270-296. https://doi.org/doi.org/10.2307/30034851.

Annajmi. (2018). Kontribusi Disposisi Matematis terhadap Prestasi Belajar Matematika Siswa Kelas VIII SMP 3 Tambusai. Edumatica, 8(1), 1-8. 
Ariyanti, G., \& Santoso, F. G. I. (2020). The Effects of Online Mathematics Learning in the Covid-19 Pandemi Period: A Case study of Senior High School Students at Madiun City, Indonesia. Mathematics Teaching Research Journal, 12(3), 4-11.

Biber, A. C., Tuna, A., \& Icikabi, L. (2013). An Investigation of Critical Thinking Dispositions of Mathematics Teacher Candidates. Educational Research, 4(2), 109-117.

Clark, L. M., DePiper, J. N., Frank, T. J., Nishio, M., Campbell, P. F., Smith, T. M., Griffin, M. J., Rust, A. H., Conant, D. L., \& Choi, Y. (2014). Teacher Characteristics Associated with Mathematics Teachers'Beliefs and Awareness of Their Students' Mathematical Dispositions. Journal for Research in Mathematics Education, 45(2), 246-284.

https://doi.org/doi.org/10.5951/jresemat heduc.45.2.0246.

Fadillah, A., Nopitasari, D., \& Pradja, B. P. (2020). Blended Learning Model During the Covid19: Analysis of Student's' Mathematical Disposition. Jurnal Teori Dan Aplikasi Matematika, 4(2), 173-181. https://doi.org/doi.org/10.31764/jtam.v4i 2.2582 .

Furner, J. M., \& Higgins, C. (2019). Empowering Teacher Leadership to Address Math Anxiety in Today's Schools. Transformations, 5(1), 4-23.

Gafoor, K. A., \& Kurukkan, A. (2015). Learner and teacher perception on difficulties in learning and teaching mathematics: Some implications. National Conference on Mathematics Teaching- Approaches and Challenges, 232-243.

Herliandry, L. D., Nurhasanah, Suban, M. E., \& Kuswanto, H. (2020). Pembelajaran Pada Masa Pandemi Covid-19. Jurnal Teknologi
Pendidikan, 22(1), 65-70. https://doi.org/doi.org/10.21009/jtp.v22i 1.15286 .

Juandi, D., Sudihartinih, E., \& Sispiyati, R. (2015). Disposisi Matematis Mahasiswa Calon Guru Matematika. https://www.researchgate.net/publication /323629027.

Khirwadkar, A., Ibrahim Khan, S., Mgombelo, J., Ratkovic, S., \& Forbes, W. (2020). Reimagining Mathematics Education During the COVID-19 Pandemi. Brock Education Journal, 29(2), 42-46. https://doi.org/doi.org/10.26522/brocked .v29i2.839.

Kilpatrick, J., Swafford, J., \& Findell, B. (2001). Adding It Up: Helping Children Learn Mathematics. National Academy Press.

Kurniawan, A., \& Kadarisma, G. (2020). Pengaruh Disposisi Matematis terhadap Kemampuan Pemecahan Masalah Siswa SMP. JPMIJurnal Pembelajaran Matematika Inovatif, 3(2), 99-108. https://doi.org/DOI 10.22460/jpmi.v3i1.p99-108.

Kusmaryono, I., Suyitno, H., Dwijanto, D., \& Dwidayati, N. (2019). The Effect of Mathematical Disposition on Mathematical Power Formation: Review of Dispositional Mental Functions. International Journal of Instruction, 12(1), 343-356.

Marpa, E. P. (2021). Technology in the Teaching of Mathematics: An Analysis of Teachers' Attitudes during the COVID-19 Pandemic. International Journal on Studies in Education (IJonSE), 3(2), 92-102. https://doi.org/doi.org/10.46328/ijonse.36.

Mazana, M. Y., Montero, C. S., \& Casmir, R. O. (2019). Investigating Students' Attitude Towards Learning Mathematics. International Electronic Journal of Mathematics Education, 14(1), 207-231. 
https://doi.org/doi.org/10.29333/iejme/3 997.

Melinda, N., \& Lazwardi, A. (2020). Kemampuan Disposisi Matematis Siswa pada Pembelajaran Daring di Masa Pandemi Covid-19. Prosiding Konferensi Nasional Pendidikan I, 59-65.

NCTM. (1989). Principles and Standard for School Mathematics. NCTM, Inc.

NCTM. (2014). Principles to Actions: Executive Summary. https://www.nctm.org/uploadedFiles/Sta ndards_and_Positions/PtAExecutiveSumm ary.pdf.

NCTM. (2020). Moving Forward: Mathematics Learning in the Era of COVID-19. https://www.nctm.org/uploadedFiles/Res earch_and_Advocacy/NCTM_NCSM_Movi ng_Forward.pdf.

Nurfallah, M., \& Pradipta, T. (2021). Motivasi Belajar Matematika Siswa Sekolah Menengah Selama Pembelajaran Daring di Masa Pandemi COVID-19. Jurnal Cendekia : Jurnal Pendidikan Matematika, 5(3), 24252437.

https://doi.org/https://doi.org/10.31004/ cendekia.v5i3.752.

OECD. (2020). Strengthening Online Learning when Schools are Closed: The Role of Families and Teachers in Supporting Students during the COVID-19 Crisis. https://www.oecd.org/coronavirus/policyresponses/strengthening-online-learningwhen-schools-are-closed-the-role-offamilies-and-teachers-in-supportingstudents-during-the-covid-19-crisisc4ecba6c/.

Sahat, H. N., Rahman, A.Y.H.A.A., Tengah, K. A., Li, H. C., \& Abdullah, N. A. (2018). A Study of Mathematics Teachers' Motivation towards Teaching in Brunei Darussalam. Journal of Studies in Education, 8(2), 18-28. https://doi.org/doi.org/10.5296/jse.v8i2.1 2732.

Simorangkir, M. R. R., Manalu, R. U., \& Masta, N. (2021). Prediction and Analysis of Mathematics Anxiety Disorder in Adolescents During the Pandemi. Solid State Technology, 64(2), 3042-3049.

Sugiyono. (2015). Metode Penelitian Pendidikan (Pendekatan Kuantitatif, Kualitatif, dan $R \& D)$. Bandung: Alfabeta.

Sumardyono. (2018). Kemampuan Guru dalam Menyusun Bukti Matematis. Indonesian Digital Journal of Mathematics and Education, 5(8), 510-522.

Taber, K. S. (2018). The Use of Cronbach's Alpha When Developing and Reporting Research Instruments in Science Education. Research in Science Education, 48(6), 1273-1296. https://doi.org/10.1007/s11165-0169602-2.

Ulia, N., \& Kusmaryono, I. (2021). Mathematical Disposition of Student'. Teachers, and Parents in Distance Learning: A Survei. Premiere Educandum: Jurnal Pendidikan Dasar Dan Pembelajaran, 11(1), 147-159. https://doi.org/doi.org/10.25273/pe.v11i1 .8869 .

Uruk, F. H. (2021). Menguak Kondisi Motivasi Belajar Siswa dalam Pembelajaran Daring pada Masa Pandemi Covid-19. Jurnal Inovasi Penelitian, 1(10), 2227-2234. https://doi.org/doi.org/10.47492/jip.v1i10 .451 .

Wijayanti, N., \& Widodo, S.A. (2021). Studi Korelasi Motivasi Belajar terhadap Hasil Belajar Matematika Selama Daring. Journal of Instructional Mathematics, 2(1), 1-9. 